\title{
Empowerment Communication in an Islamic Boarding School as a Medium of Harmonization
}

\author{
ADHI IMAN SULAIMAN \\ Jenderal Soedirman Universitas, Indonesia \\ DADI AHMADI \\ Universitas Islam Bandung, Indonesia
}

\begin{abstract}
The study aims to analyze empowerment communication in a cooperative of an Islamic boarding school as a medium of harmonization. The study used a qualitative research method for Participatory Learning and Action (PLA). Data were collected through interviews, documentation, observation, and Focus Group Discussion (FGD). Informants were selected purposively and snowball sampling, namely the organization committee and students at the Islamic Boarding School, the management of cooperatives, business groups in the community, and village government, as well as practitioners, and activists of community empowerment. The study location was determined in community and Al Muaddib Islamic boarding school at Cilacap district, Central Java Province of Indonesia. The study used data analysis of community development, namely identifying, categorizing problems, specific objectives, analyzing problems and preparing action plans, evaluating the entire process, and action plans. The results of research i.e. (1) The empowerment communication should be developed to perform a comprehensive economic empowerment program ranging from the identification of the problem, the potential of human resources, natural resources and the economy of rural communities up to the analytical solution of cooperative programs, assistance and partnerships to realize harmonization. (2) Empowerment communication should be carried out sustainably and comprehensively with a humanistic, dialogical, egalitarian and participatory approach starting from counselling to provide motivation, inspiration, knowledge, and then improving skills with training, monitoring, evaluation and partnership. (3) The study implication is that empowerment communication programs could be a medium for harmonization, eliminating traumatic and negative stigma against society and Islamic boarding school which are considered radical.
\end{abstract}

Keywords: Boarding school, cooperative, empowerment communication, harmonization, negative stigma.

\section{INTRODUCTION}

Community welfare is determined by the process and implementation of development at the village level that carries out participatory communication among stakeholders to become the foundation of urban economic strength and avoid conflicts caused by economic inequality, marginalization and lack of communication opportunities which are able to aspire and participate in designing rural development programs. Participatory development is an empowerment communication that provides an opportunity for all parties to aspire and be involved in the formulation and implementation of development programs based on the identification and analysis of problems, potential resources and needs. 
Therefore, participatory communication in development is empowerment communication which makes development programs belong to and joint responsibility among all stakeholders (Bordenave, 2004; Leeuwis, 2009; Christens, 2012; Thomas, 2014; Ahmadi, 2019. The paradigm that emphasizes economic growth, equitable development and growth-oriented development has a massive impact on environmental damage, poverty and economic inequality. Thus, development needs a new strategy or development paradigm that focuses on improving the quality of human resources. The development paradigm that must be applied is people centered development with the core being that human resources have knowledge and abilities as a requirement for human capacity not only to become the subject of development but also and not only as an object of development.

Empowerment communication becomes effective in opening access, approaches and research with action research as a socio-economic rehabilitation of community situations that experience trauma, negative stigma, hidden conflicts between the community and the Al Muaddib Islamic Boarding School in Cilacap Regency which was caused by the arrest of terrorism by Noerdin M. Top and his wife as well as his father in law between the years 2009 - 2010 that were very famous and phenomenal and became public attention both nationally and internationally. Based on the results of preliminary research in 2011-2014, after the three arrests of terrorism occurred, the people of Pasuruhan village, Binangun Subdistrict, Cilacap Regency, Central Java Province was unable to interact harmoniously with the Al Muaddib Islamic Boarding School which received a negative assessment or stigma as a radical, closed, unsocialized and have different religious schools with society. Therefore, the Al Muaddib Islamic Boarding School is marginalized and isolated. It also creates hidden conflicts and disharmony with society. When researchers as academics try to implement approaches and open access, they find it difficult to be able to interact with the Al Muaddib Islamic Boarding School because of the construction of a radical and closed negative stigma, disharmony and hidden conflicts with the surrounding community.

However, researchers have good intentions and want to conduct research while at the same time try to carry out socio-economic rehabilitation to create harmony and eliminate negative stigma. They are able to successfully interact with Al Muaddib Islamic Boarding School by (1) Initially, the boarding school still harboured suspicion and still did not welcome the researchers because they thought that the interaction and offer of empowerment programs were manipulated to detect and re-arrest several people at the boarding school by security forces. However, persuasive communication, participatory communication and personal communication that continue to be carried out can be successfully accepted by the empowerment program agenda with the initial stage of identifying and analyzing the very fundamental problems faced by the boarding school, namely the trauma and negative stigma faced by the boarding school as a result of the arrest of terrorism; (2) Continue to establish communication and maintain the credibility of the good name of the neutral and independent academic community with the community and Islamic boarding schools by using participatory communication or empowerment communication, who are very concerned about the problems and needs to improve economic welfare. Thus, the next stage is to carry out a dialogue forum as a form of empowerment communication to identify and analyze problems, potentials and needs in the economic sector in Islamic boarding schools by designing, implementing extension programs, training and mentoring economic business groups to be formed or existing business groups, namely chicken, fish farms, catfish and ducks, plantations for red ginger and cooperative institutions; (3) Empowerment communication can be realized by conducting counselling and training on entrepreneurship management or business group 
management of sharia cooperatives. Subsequently carried out counselling and training on animal husbandry and plantation cultivation. This empowerment communication involves practitioners and experts in the field of entrepreneurship and sharia cooperatives who have succeeded in becoming Muslim entrepreneurs as examples, motivation and inspiration to carry out assistance and cooperation; (4) All this time Islamic boarding schools have maintained religious fields such as mastery of the Al-Quran, Al-Hadith and sharia that have become the focus of education orientation. Therefore, they consider the economic and entrepreneurial business fields to be the orientation of parties outside the boarding school. However, with the empowerment communication through various suggestions and recommendations from various inspirational examples of successful muslim and boarding school entrepreneurs in entrepreneurship and cooperatives. Thus the boarding school can carry out economic empowerment as part of the educational orientation and development of the boarding school to provide motivation, inspiration, knowledge, skills and welfare for students and alumni in the field of economic entrepreneurship.

The advanced research stage in the 2015-2018 period, empowerment communication has involved the community around the boarding school, thus the empowerment program that has been implemented with the next stage of the Islamic Boarding School can involve community groups. Empowerment communication is carried out by involving students and local governments such as the small and medium enterprise empowerment office and cooperatives, and district extension offices. Programs designed in the form of community service, practicum, student internships and real work lectures. Therefore, the empowerment program that has been initiated and implemented continues to receive assistance and partnerships such as the establishment and registration of a Sharia Cooperative which was established jointly between the village community and the Islamic Boarding School to provide the needs for equipment, fertilizers and agricultural seeds. Followed by training on the formation and business development of organic rice farmer groups, bamboo weaving crafts and catfish farming. Based on the research results for three periods starting from 2011-2014 and 2015-2018, the participatory development strategies have become a model for developing motivation, mindset, attitudes, skills, institutional capacity and cooperation through communicative participation as empowerment communication.

Participatory development communication as planned activities are based on a participatory process, the role of the media and interpersonal communication that facilitates dialogue between stakeholders on problems and common development goals to develop and implement program solutions (Bessette, 2004). Empowerment communication has a theoretical framework that is based on participatory communication and development but is specifically directed towards supporting research agendas that facilitate social transformation and equality (McPhail, 2009). The main idea of the people centered development paradigm is based on community participation as a bottom-up communication model, while top-down communication or diffusion models are tools used in the modernization and dependency paradigm by using persuasion patterns in one-way communication to change attitudes and their behaviour, while the participatory model with dialogical communication managed by development actors (Servaes, 2008). Participatory communication has been regarded as development as the transmission of knowledge. Mass media is the main tool for conveying messages from the center to the periphery with one-way communication, therefore it was changed in development with a new idea of participatory communication as the core of people-centred development (Musakophas, 2017). 
Therefore, it is important and interesting to carry out research of empowerment communication as mediation, rehabilitation and harmonization between the community and Islamic boarding schools, who still undergo traumatic and negative stigma as radical and terrorist communities.

\section{METHODOLOGY}

The research used Participatory Learning and Action in a form of qualitative research to identify problems and potentials of the community and gain a deep understanding of the situation of a community as a community worker to analyze and make decisions on problems, potential resources owned and community needs (Appel, 2012). The Participatory Learning and Action method are very relevant to be used for participatory research which requires openness, closeness, harmony and cooperation to carry out empowerment programs as research media. The research was carried out from September 2019 to March 2020 because there was social distancing due to the COVID-19 Pandemic. The research could then be continued from July to October 2020. The research took place in the community and Al Muaddib Islamic boarding school in Pasuruhan village of Binangun Sub-district, Cilacap district, the Province of Central Java, Indonesia. Research data was collected through interviews, direct observation, documentation and Focus Group Discussion. Research informants were selected purposively and by snowball sampling, namely the organization Committee and students at the Islamic Boarding School, the management of cooperatives, business groups in the community and village government, then practitioners, activists, and experts in the field of community empowerment. The research used data analysis of community development (Huraerah, 2011), namely identifying, categorizing problems, general and specific objectives, then analyzing problems and preparing action plans, evaluating the entire process, and action plans.

\section{RESULTS AND DISCUSSION}

Based on the stages of the research process which is full of challenges with problems of the negative stigma, traumatic feelings and hidden conflicts, the researchers are interested in continuing the research in 2019-2020 with a participatory, dialogic and humanistic approach to empower communication in society and the Al Muaddib Islamic Boarding School. Because creating and managing a peaceful situation with each other by openness, communicative and collaboration can be done through the media and empowerment communication as rehabilitation, mediation and socio-economic harmonization between the Islamic boarding school and the surrounding community.

\section{The Reality of Empowerment Communication in Islamic Boarding School Cooperative}

The research phase in the period of 2019 - 2020 is a form of monitoring and evaluation that can be carried out while continuing to carry out research and community service through empowerment communication with an orientation to the problems, needs and potentials of Islamic boarding schools and village communities. The results of monitoring and evaluation show that the Islamic cooperative has become a legal entity that continues to provide agricultural needs, has increased membership of around 300 people and has become the holding company for community economic enterprises with the support of the village government. Duck and catfish farming business groups, woven bamboo handicraft groups that make birdcages, chicken coops, broomstick crafts, and organic rice farming have also increased in terms of product quality and quantity, increased marketing and income due to affordable access to large-scale markets and strategic. The management of cooperatives is 
managed by the community and the boarding school is busier with the development of their educational institutions, but they continue to involve all parties and run economic businesses such as animal husbandry, agriculture and plantations.

Community participation and Islamic boarding schools remain enthusiastic when innovative empowerment programs are held by redesigning empowerment programs based on problems, needs and potentials, namely counselling, training and mentoring for herbal plant cultivation as well as herbal plant processing. However, there is still a dualism of pros and cons among the board of boarding school who are open to continue to accept and be involved in empowerment activities with parties who still refuse to be involved due to of suspicion and do not have the same thought, as they are a new member of the boarding school who joined in 2019 and have not been involved in the previous program. Therefore, it requires a communication process to create mutual understanding. It needs strategies and support for various forms of communication such as persuasive communication, interpersonal communication, group communication, convergence, participatory communication or empowerment communication. Moreover, the communication involves all elements between the researcher and the village government, community leaders, leaders and administrators at the Islamic Boarding School and practitioners and experts who become instructors and assistants in empowerment activities.

Starting from February 2020 the Covid 19 Pandemic occurred with the existence of large-scale social restriction regulations, the empowerment program was hampered and temporarily stopped. Empowerment activities began to be resumed in August 2020 when they started to get permission to resume activities while still using health protocols. Research and community service are still carried out through participatory, open, dialogic and egalitarian empowerment communication, some program activities can finally be designed and agreed upon based on the needs of the boarding school community, namely strengthening the cooperative as a holding company by conducting digital administrative and financial management training, promotion management and marketing of economic business products through social media. The regeneration of the management of cooperatives and business groups as part of an empowerment strategy for developing and strengthening institutions while maintaining its orientation to carry out mediation and socio-economic rehabilitation for harmony and to improve mutual welfare. However, empowerment communication must also create independence in the community so that the regeneration of empowerment actors in Islamic boarding schools and villages can become companions and pioneers for the sustainability of empowerment programs, including socio economic rehabilitation and harmonization between Islamic boarding schools and surrounding communities. Empowerment as informal and non-formal education for the community through institutional development of small and medium economic enterprises or entrepreneurship is based on local resources and it must be participatory by involving all parties and continuously become a strategic program in the community.

Empowerment is a fundamental process and leadership education for community development (Pigg, 2002). Empowerment is the result of interpersonal (mutual empowerment) and collective action (social empowerment), and then community development must have a set of competencies that can be accepted by the public as an effort to build a community in equality and democratic manner (Greve, 2003). The importance of a community leadership development education program designed to develop the capacity of individuals as leaders in the community and contribute to resolving 
the critical condition of individuals in the community by increasing knowledge and effective leadership skills. Leadership education programs can also increase human capital and social capital in society as well as improvements in culture, politics, nature and finance (Apaliyah, 2012). Implementation of development projects that must preserve indigenous cultures, and then the implementation of community empowerment with education has been able to design and implement sustainable development programs (Lara, 2018). Educational policies, students" background (social and economy) and how important the subjects for the future are part of aspects should be understood to support the good learning (Ahmadi, 2020). Decentralized cooperation provides a favourable climate for implementing alternative development strategies, for example, those suggested by the Local Human Development approach. Most of the entrepreneurs adopt the concept of empowerment which is related to the communication act of leadership which must be able to transfer social awareness and skills, as well as increase motivation (Sudarmanti, 2015). The Community empowerment should create a reciprocal relationship between companies or social institutions and the community, such as in a Corporate Social Responsibility project so that activities become common interests, goals, and welfare (Widhagdha, 2019).

Participation is an empowerment communication has been carried out in a sustainable manner to use and increase motivation, thinking, skills and real cooperation to shared problems and to achieve expected needs in an effort to bring some changes to community life. Islamic boarding schools and communities have potential in developing economic enterprises such as owning suitable and successful land in cultivating red ginger and plants such as tubers, cassava and taro, then cultivating catfish, goat livestock, and woven bamboo crafts. Cooperatives can also be developed by providing basic necessities, agricultural equipment, fertilizers and agricultural seeds. Economic business groups can be used as cooperative business units, so that membership, capital and finance will be more productive by providing affordable savings and loans or helping to capitalize on the business.

Islamic boarding school cooperatives can also require students and their parents, including suggest their alumni to become members of the cooperative by paying savings to strengthen business capital. Cooperatives become the center of Islamic boarding schools and community economic institutions that anticipate moneylenders, which often unsettle village society by lending money with high-interest rates. Islamic boarding schools and society can be mediated by researchers as academics to design empowerment programs in a participatory and collective manner such as providing counselling about motivation and inspiration about entrepreneurship and successful business groups, the benefits of cooperatives, and developing cooperatives as a joint economic force, training and mentoring entrepreneurship and cooperative management, administrative and financial management, membership management, and promotion and marketing strategies.

The process of communicating empowerment in the community and institutional arrangements as a conceptual framework and orientation that can be a solution to global problems. Community empowerment communication has advantages and uniqueness to encourage the process of joint decision making, development, welfare and through appropriate technology for sustainable development based on local resources (Ife, 2006; Christens, 2012; Sianipar, 2013; Wahid, 2017.

Islamic boarding school cooperative empowerment program and entrepreneurship can be carried out in a sustainable manner; it is necessary to enter the curriculum as optional or additional subject matter and practice for students so that they have enthusiasm, 
knowledge and skills in entrepreneurship and managing cooperatives. Before even graduating, students are required to do internships or practical work in economic business groups and cooperatives in order to have experiences, inspiration and networking. Islamic boarding school cooperatives also involve and cooperate with local community business groups in order to create harmony and eliminate negative stigma. The sustainability of cooperatives is also determined by empowerment communications carried out by the village community and the Islamic boarding school with the participation of researchers from universities to become mediators and facilitators including local governments.

The concept of community empowerment cannot be separated from sustainability and sense of togetherness, because these three concepts are the key to success in community development. The solidarity and cooperation with the community that will strengthen of connection among members of the groups or communities to be able to work together to implement programs and achieve common goals (Ahmad, 2016). Economic empowerment for the community is an effort to increase the capacity or potential of the community in economic activities aimed at fulfilling life needs and increasing welfare, so as to increase national resilience (Supandi, 2016). Community empowerment emphasized that community empowerment has been able to develop internal potential and external potential from around the community. Empowerment needs support and cooperation from all stakeholders, namely government, private sector and academics (Mafruhah, 2018). Participatory development communication has an emphasizes to openness, egalitarianism and dialogue, that is relevant in carrying out economic empowerment and incorporating Islamic economic subjects of Islamic boarding schools and economic business activities to become a medium of kindness (Sulaiman, 2018). Community empowerment needs to take advantage of community development strategies by using sources of support from external actors as an exogenous practice and utilizing assets from within the community as an endogenous practice. There is a model of involvement, participation, and empowerment which shows the stages in providing knowledge, skills, and power from external actors to local communities (Steiner, 2017). Empowerment communication is the most important part of participation in implementing decisions and programs (Ahmadi, 2019). Participation in public involvement to making and implementation of joint decisions or public policies. Empowerment communication is a humanist communication process, providing opportunities for people to aspire to their needs, who are unable to aspire (voicing the voiceless) (Setyowati, 2019).

\section{Empowerment Communication Model in Islamic Boarding School Cooperative}

The empowerment model is a representation of the importance of communication that is dialogic, harmonious, open-minded and equal between researchers and research subjects in the process of identifying and analyzing problems, potentials, and resources. Empowerment model will be detailed with materials, methods, time and indicators of empowerment activities. The empowerment model has been communicated in various stages of empowerment activities, starting from counselling, training, mentoring and partnerships. The empowerment model has been a result of design, determination and implementation by students, parents of students, alumni, teachers and board of Islamic boarding school, and the surrounding community. so that it will foster solidarity, sense of belonging, cooperation and harmony. The main actors of empowerment communication are santri, parents of students, alumni, teachers and board of Islamic boarding school, as well as the surrounding 
community designing, agreeing, implementing and evaluating empowerment models so that they will build solidarity, sense of belonging, cooperation and harmony.

Based on practical experiences and several research results, making empowerment programs strategies must be through participatory communication that is egalitarian, humanist and democratic for all parties, especially providing the community has the opportunity to participate in communicating in the formulation of plans, agreements, implementation, monitoring and evaluation of empowerment programs. By doing so, the empowerment of program strategies will be in accordance with the identification and analysis of problems, potential resources and community need to achieve harmony, cooperation, welfare and independence of community.

Participation emphasizes that the community must be involved in research projects or empowerment actions, so that they can solve problems, realize their needs from the community's point of view and commit to supporting, collaborating and succeeding the program in a sustainable manner (Cadiz, 2005). Development and empowerment communications need the attention of educational institutions to be included in curriculum materials for optional or additional subjects. Educational institutions such as Islamic boarding schools must be sensitive and open to respond to changes, demands and challenges of the times, especially in economic dynamics. Educational institutions can produce practitioners and economic actors such as entrepreneurs and managers of cooperatives as educational institutions that provide services and the realization of welfare for the community (Sulaiman, 2016). Participatory communication as a message and meaning constructed by all parties who are given the opportunity to open dialogue, reach understanding and agreement in the form of collective decisions. Although in the implementation of participatory communication is still low at the empowerment program stage in the aspects of planning, monitoring and evaluation. The ideal dialogue situation has not been optimally implemented in the empowerment program in the aspects of equality, independence and argumentation (Aminah, 2016).

The Islamic boarding school must communicate empowerment with internal parties between the santri and pesantren management and parties outside the pesantren, in this case, the surrounding community such as alumni, government and other educational institutions to analyzing the situation and needs for the social-economic development of the pesantren. Empowerment of communication can be carried out by various parties by academics who are still considered objective, neutral and uninterested. The problems of disharmony, negative stigma and hidden conflicts caused by Islamic boarding schools are considered radical and terrorist place. The problems in designing and implementing empowerment programs have indeed found in the results of research such as persuasive and cooperative communication or participatory communication that cannot be implemented due to the lack of understanding that communication must be dialogical, open, equal and listening to each other as empowerment communication. Facilitators from researchers or activists can become empowerment communicators to mediate disharmony, hidden conflicts and traumatic feelings in the community, and connect between government agencies and their policies to be able to support and collaborate in community empowerment based on problems, potentials and real needs of this as empowerment communication.

The Islamic boarding school has implemented subject matter on economic empowerment, cooperative management and entrepreneurship, so students and alumni will have inspiration, motivation, knowledge, and entrepreneurial and managerial skills of 
cooperatives, as well as learn participatory empowerment communication. By doing so, they will be able to implement comprehensive and sustainable empowerment communication model, because alumni will be able to become instructors and assistants to carry out counselling, training, mentoring and to create partnership access. This is a manifestation of the empowerment communication model in the development of cooperative institutions that could be used as a medium for interaction, cooperation, mutual assistance, and harmonization, so that eliminated negative stigma between Islamic boarding school and society.

The participatory approach of communication as an effort in development to replace the focus orientation on modernization, knowledge diffusion and technology transfer. Furthermore, development can no longer depend on the transfer of knowledge from outside the community, but focuses on local knowledge, local capabilities and community participation in planning and implementing development (Jacobson, 2003). Participatory communication strategies have very specific perspectives on articulating social processes, decision making, and change. Participatory approaches are not new, but many institutions, especially the government and also non-governmental organizations (NGOs) are pursuing a participatory approach in their development initiatives as something that is currently emerging (Tufte, 2009). Highlight that the power of communication contributes to the success of an activity or program implementation, then the power of information and relational strength is strongly correlated with each other, even though the power of information is more practiced than relational power (Wok, 2014). Participatory communication has become an important element in building linkages between studies in the field of conflict management and power, which is sometimes less distributed and less supportive of society (Chin, 2018). Strategic communication has relevance and determines the impact of organizational dynamics and progress, with various aspects, namely the focus of communication, communication channels, the substance of communication meaning and communication styles. Another aspect is the role of leadership, interpersonal relationships, design, implementation and assessment of communication (Mahbob, 2019). Empowerment communication model can be designed in the development of Islamic Boarding School Cooperatives as a medium of harmonization, anticipating negative stigma and traumatic feelings due to conflicts from the arrest of terrorism, as in Figure 1. 


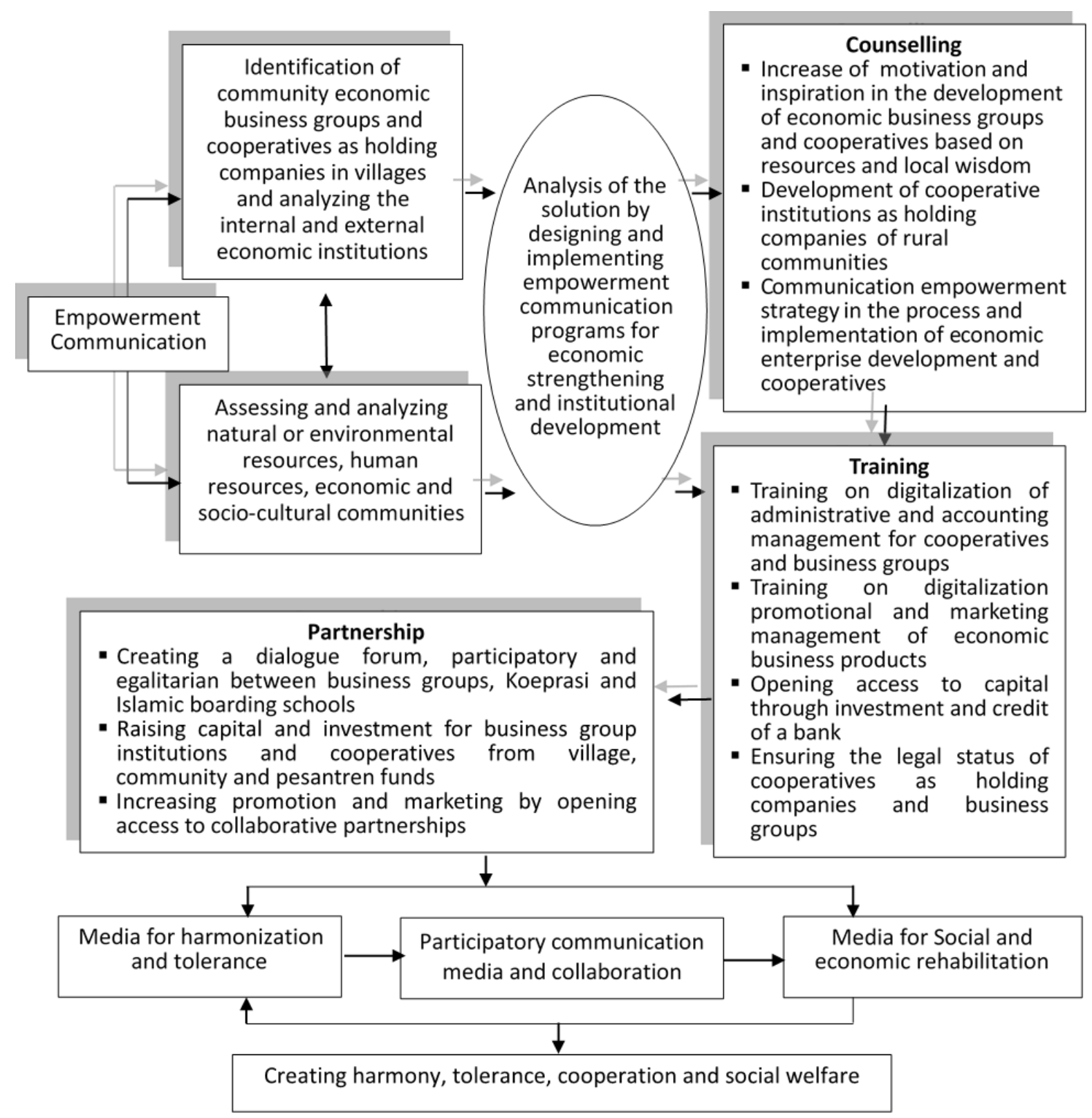

Figure 1: Empowerment communication model as a medium for rehabilitation and harmonization

Based on the empowerment communication model in Figure 1, it can be explained that the empowerment communication in the cooperative economic model can be summarized and analyzed with reference to two aspects: (1) Problems Identification i.e. increasing the quantity of membership, market access, partnership access, and solid cooperation access; and (2) Potentials Identification of the Society, i.e. farmer groups and business groups in the village of Pasuruhan could potentially be a new board member and group empowerment. Cooperative board, farmer groups and business groups have an interest and high motivation to develop business. Market share is very open and prospective with close and easy access to the markets nearest to the village. The business has been running long enough. The next stage is to increase productivity in order to meet the marketing needs elsewhere; (3) Analysis of Solution i.e., Perform openly membership recruitment and socialization to the public to join in cooperatives and business groups. In 
addition, improving the quality and quantity of production to meet market needs, performing regular meeting to evaluate and create business solutions and develop a business program, establishing access to the investor for the convenience lending business capital, performing meetings with members of the group to actively join in a cooperative, and conducting a dialogue with the management of cooperatives, farmers' groups and business groups as well as the village government are crucial to execute; (4) Monitoring and Evaluation i.e. Extension and assistance from the year 2019-2020 has been conducted regularly every semester about the benefits of doing business in the group through the institutions. Pasuruhan village government can support and help in strengthening the institutional community development. Cooperative Agency of Cilacap Regency has been invited to provide counselling and mentoring. Cooperative, farmer groups and business groups have been given counselling and training on strategies for improving the promotion and marketing.

Economic business groups from the community and Islamic boarding school can support each other and work together instead of becoming a competition so that the development of community and Islamic boarding school cooperatives into economic institutions to bring together all economic groups into business units can be established. Cooperatives have even become a medium of interaction and harmonization between society and Islamic boarding school that can anticipate traumatic feelings, negative stigma about radical communities and disharmony. Therefore, designing and implementing a communication model for community empowerment and Islamic boarding schools is very important and strategic.

Islamic boarding schools provide benefits to students in terms of social entrepreneurship education that is given implicitly in several subjects and then can also be practiced in social entrepreneurial institutions with the aim of practicing theoretical concepts with system applications as part of deepening or complementing the science of social entrepreneurship and will be continued entrepreneurship outside and in other social entrepreneurial institutions (Reginald, 2014). The Strategic and important role of santri (student), kiai (teacher) and alumni in entrepreneurship development at Islamic boarding schools namely: (1) Independence for worship intentions has expected achievement; (2) Values of goodness can be applied such as transparency, acceptance, and professionalism; (3) Management can apply a culture of honesty and trustworthiness. These three elements are a manifestation of the management and development strategy of Islamic cooperative institutions and entrepreneurship based on the culture of Islamic boarding school, which do have unique and different characteristics (Siswanto, 2018). The Islamic boarding school cooperative model in social-economic empowerment of student make an important point by creating and improving enthusiasm, knowledge, and skills in organizational management, administration, accounting, cooperation networks for institutional development of cooperatives and economic business units that have characteristics in accordance with the characteristics of society and Islamic boarding schools such as fisheries, livestock, agribusiness, agro-industry, trade and the service sector for the welfare of society and Islamic boarding schools (Sulaiman, 2018). The concepts and studies developed and empirical facts in Islamic boarding schools, which have an important instruction to develop entrepreneurial spirit and skills. Islamic boarding school should implement a curriculum of science and technology, skills and entrepreneurship. The government has the responsibility to motivate and facilitate aspirations and capacities to develop entrepreneurial spirit and 
skills for Islamic boarding school, that have not implemented an entrepreneurial curriculum (Indra, 2019).

The empowerment communication model which has been designed, approved, produced and implemented is a participatory communication process that involves all parties such as the community, local government, private sector, academics, development practitioners and activists, so as to build more awareness, togetherness, and cooperation in solving problems, as well as manage potential sources power and achieve mutual prosperity. The actor of social worker actors, facilitators, and empowerment activists has carried out the empowerment communication model from such stages as extension, training, mentoring and partnership, essentially involving various parties who need cooperation and solidarity. Persuasive and imperative communication is the key to the successful formulation, determination and implementation of programs that need to be considered and implemented by all parties as a shared commitment.

The importance of cooperative communication would be to create interaction and cohesiveness, this was needed to develop groups in various training activities to improve capabilities and skills in carrying out institutional or group tasks (Bakar, 2017). The effective persuasive communication is important to help community members towards an optimistic attitude change, with indicators providing opportunities to speak, to improve self-confidence, to have good emotional control, to promote friendliness, and to have a lot of vocabulary and appreciate cultural differences (Kamaruddin, 2017). Persuasive communication skills are very important for social workers with strong capacities, emotional mastery, message appeal, organizational skills, and cultural knowledge in serving and providing consultation or assistance. Persuasive communication is a mentoring strategy that can be used by activists, facilitators, extension workers and empowerment activists to implement approaches, open access, provide motivation, mindset, understanding, action and collaboration between groups and communities as beneficiaries (Suranto, 2019).

The communication model for community empowerment and Islamic boarding schools requires support from the government, especially the education office to make policies for economic, entrepreneurial and cooperative subjects into the Islamic boarding school curriculum so that they can create an Islamic economic community and students after graduation can become independent successful entrepreneurs, as not all of them become Koran teachers and religious educators. To this relation, support from government agencies in the field of community economic empowerment promoting the sustainable empowerment program of Islamic boarding school cooperatives is necessary. Facilitators, especially academics, researchers and empowerment activists, become mediators and creators in connecting partnerships among Islamic boarding schools, society, and government and other parties to work together. This is the essence of empowerment communication, which also has the aim of making entrepreneurship in cooperatives as a medium for harmonization between Islamic boarding schools and society from negative stigma, traumatic experiences, and social conflicts.

\section{CONCLUSION}

Stages of implementation and evaluation of empowerment communication model were carried out by action research with empowerment strategy through extension, training, mentoring and partnerships which are implemented in a way that are (1) Participatory; the establishment of empowerment communication model must involve the community in formulating and making the institutional empowerment, which is based on the identification 
and analysis of problems, potential and available resources; (2) Comprehensive; the implementation of empowerment communication model through empowerment programs should be comprehensive and sustainable, including extension, training, mentoring and partnerships; (3) Cooperative; the implementation of a model is a form of cooperation or partnership between the villagers and the village government with other parties such as universities, local governments and private parties as well as banks.

Empowerment communication model has become the psychological and social rehabilitation media as well as a media of interaction and harmonization of covert conflicts, traumatic sense, mutual suspicion and negative stigma caused by terrorist incidents. Empowerment communication model in turn can be used as participatory and cooperative media in formulating and making decisions together, especially economic empowerment programs as a strategy to improve the social and economic well-being of rural communities.

\section{ACKNOWLEDGEMENT}

Dear Institute for Community Services of Jenderal Soedirman University and Universitas Islam Bandung (UNISBA), and the Directorate General of Higher Education, Ministry of Education and Culture, Republic of Indonesia, we would like to thank the policies and support for our research activities, so that we can complete and publish the research results in Jurnal Komunikasi: Malaysian Journal of Communication.

\section{BIODATA}

Adhi Iman Sulaiman is an empowerment activist and senior lecturer at Faculty of Social and Political Sciences, Jenderal Soedirman University, Indonesia. His research expertise is on communication, development and community empowerment. Email: adhi.2005unsoed@gmail.com

Dadi Ahmadi is a senior Lecturer at Faculty of Communication, Universitas Islam Bandung, Indonesia. His research interests include medium, public relation net, public information disclosure, technology communication. Email: dadi@unisba.ac.id 


\section{REFERENCES}

Ahmad, M. S., Talib, A. N. B. (2016). Analysis of community empowerment on projects sustainability: Moderating role of sense of community. Soc Indic Res, 129, 1039-1056. https://doi.org/10.1007/s11205-014-0781-9

Ahmadi, D., Rachmiatie, A., \& Nursyawal. (2019). Public participation model for public information disclosure. Jurnal Komunikasi: Malaysian Journal of Communication, 35(4), 305-321. https://doi.org/10.17576/JKMJC-2019-3504-19

Ahmadi, D., \& Yanuarti, E. (2020). Reflective writing: Students' diaries to improve the teaching and learning process. Paper presented at Conference 2nd Social and Humaniora Research Symposium (SoRes 2019) (pp. 521-524). https://doi.org/10.2991/assehr.k.200225.113

Aminah, S. (2016). The application of participatory communication in the implementation of small farmers empowerment program. Jurnal Bina Praja: Journal of Home Affairs Governance, 8(1), 135-148. https://doi.org/10.21787/jb.08.2016.135-148

Apaliyah, G. T., Martin, K. E., Gasteyer, S. P., Keating, K., \& Pigg, K. (2012). Community leadership development education: promoting civic engagement through human and social capital, Community Development, 43(1), 31-48. https://doi.org/10.1080/15575330.2011.645043

Appel, K., Buckingham, E., Jodoin, K., \& Roth, D. (2012). Participatory learning and action toolkit: For application in BSR's global programs. Kenya: BSR's Global Programs.

Bakar, H. A. (2017). Explaining cohesion linkages in workgroups: The cooperative communication in collectivism and high power distance workgroup context. Jurnal Komunikasi: Malaysian Journal of Communication, 33(3), 157-177. https://doi.org/10.17576/JKMJC-2017-3303-10

Bessette, G. (2004). Involving the community: A guide to participatory development communication. Malaysia: Southbound.

Bordenave, J. D. (2004). Participative communication as a part of building the participative society. S. A. White, K. S. Nair., \& J. Ascroft (Eds.), Participatory communication: Working for change and development. London: Sage Publications.

Cadiz, M. C. H. (2005). Communication for empowerment: The practice of participatory communication in development. Buenos Aires: CLACSO, Consejo Latinoamericano de Ciencias Sociales.

Chin, S. Y. (2018). Participatory communication in practice: The nexus to conflict and power. Switzerland: Springer.

Christens B. D. (2012). Targeting empowerment in community empowerment: A community psychology approach to enhancing local power and well-being. Community Development Journal, 47(4), 538-554. https://doi.org/10.1093/cdj/bss031

Greve, A., \& Salaff, J. W. (2003). Social networks and entrepreneurship. Entrepreneurship Theory and Practice, 28(1), 1-22. https://doi.org/10.1111/1540-8520.00029

Huraerah, A. (2011). Pengorganisaian dan pengembangan masyarakat: Model dan strategi pembangunan berbasis kerakyatan. Bandung: Humaniora.

Ife, J., \& Tesoriero, F. (2006). Community development: Community-based alternatives in an age of globalisation. Australia: Pearson Education.

Indra, H. (2019). Pesantren dan pendidikan entrepreneurship. Edukasi: Jurnal Penelitian Pendidikan Agama dan Keagamaan, 17(2), 188-198. http://dx.doi.org/10.32729/edukasi.v17i2.600 
Jacobson, T. L. (2003). Participatory communication for social change: The relevance of the theory of communicative action. Annals of the International Communication Association, 27(1), 87-123. http://dx.doi.org/10.1080/23808985.2003.11679023

Kamaruddin, A. (2017). Analisis kualitatif terhadap faktor kegagalan komunikasi pembujukan dalam konteks pengucapan awam. Jurnal Komunikasi: Malaysian Journal of Communication, 33(3), 89-106. https://doi.org/10.17576/JKMJC-2017-3303-06

Lara, C. S., Crispin, A. F., \& Tellez, M. C. L. (2018). Participatory rural appraisal as an educational tool to empower sustainable community processes. Journal of Cleaner Production, 172, 4254-4262. https://doi.org/10.1016/j.jclepro.2017.08.072

Leeuwis, C. (2009). Communication for rural innovation: Rethingking Agricultural Extension with contributions from Anne van den Ban. UK: Blackwell Publishing.

Mafruhah, I., Mulyani, N.S., Istiqomah, N., \& Ismoyowati, D. (2018). Development of ecotourism based on community empowerment (A case study of Kebumen regency). Jurnal Ekonomi Pembangunan: Kajian Masalah Ekonomi dan Pembangunan, 19(2), 196-206. https://doi.org/10.23917/jep.v19i2.6996

Mahbob, M. H., Ali, N. A. S. M., Sulaiman, W. I. W., \& Mahmud, W. A. W., (2019). Komunikasi strategik dan peranannya untuk mewujudkan komunikasi berkesan dalam organisasi. Jurnal Komunikasi: Malaysian Journal of Communication, 35(2), 49-67. https://doi.org/10.17576/JKMJC-2019-3502-04

McPhail, T. L. (2009). Development communication: Reframing the role of the media. United Kingdom: Wiley-Blackwell Publishing.

Musakophas, R., \& Polnigongit, W. (2017). Current and future studies on participatory communication in Thailand. Kasetsart Journal of Social Sciences, 38(1), 68-73. https://doi.org/10.1016/j.kjss.2016.01.011

Pigg, K. E. (2002). Three faces of empowerment: expanding the theory of empowerment in community development. Journal of the Community Development Society, 33(1), 107-123. https://doi.org/10.1080/15575330209490145

Reginald, A. R., \& Mawardi, I. (2014). Kewirausahaan sosial pada Pondok Pesantren Sidogiri Pasuruan. Jurnal Ekonomi Syariah Teori dan Terapan, 1(5), 333-345. http://dx.doi.org/10.20473/vol1iss20145pp333-345

Servaes, J. (2008). Communication for development and social change. UK: SAGE.

Setyowati, Y. (2019). Komunikasi pemberdayaan sebagai perspektif baru pengembangan pendidikan komunikasi pembangunan di Indonesia. Jurnal Komunikasi Pembangunan, 17(2), 188-199. https://doi.org/10.46937/17201926849

Sianipar, C. P. M., Yudoko, G., Adhiutama, A., \& Dowaki, K. (2013). Community empowerment through appropriate technology: Sustaining the sustainable development. Procedia Environmental Sciences, 17, 1007-1016. https://doi.org/10.1016/j.proenv.2013.02.120

Siswanto. (2018). The exploration of pesantren - Based entrepreneurship development strategy through teleology approach. El Harakah: Jurnal Budaya Islam, 20(2), 191-213. http://dx.doi.org/10.18860/el.v20i2.5253

Steiner, A. A., \& Farmer, J. (2017). Engage, participate, empower: Modelling power transfer in disadvantaged rural communities. Environment and Planning C: Politics and Space, 36(1), 118-138. https://doi.org/10.1177/2399654417701730 
Sudarmanti, R., Bauwel, S. V., \& Longman, C. (2015). Women's empowerment: Examining leadership communication of women entrepreneurs in Indonesia and The USA. Jurnal Komunikasi: Malaysian Journal of Communication, 31(1), 157-170. https://doi.org/10.17576/JKMJC-2015-3101-08

Sulaiman, A. I. (2018). Komunikasi Pembangunan melalui program pemberdayaan sebagai materi pembelajaran di pesantren. Jurnal Komunikasi Pembangunan, 16(2), 286-296. https://doi.org/10.46937/16201826342

Sulaiman, A. I. Chusmeru, \& Masrukin. (2018). Strategy of cooperative Islamic boarding school as economic empowerment community. Inferensi: Jurnal Penelitian Sosial Keagamaan, 12(1), 25-44. http://dx.doi.org/10.18326/infs|3v12i1.25-44

Sulaiman. A. I., Masrukin, Chusmeru, \& Pangestuti, S. (2016). Pemberdayaan koperasi pondok pesantren sebagai pendidikan sosial dan ekonomi santri. JPPM: Jurnal Pendidikan dan Pemberdayaan Masyarakat, 3(2), 109-121. https://doi.org/10.21831/jppm.v3i2.11303

Supandi., Sahabuddin, Z. A., \& Amperiawan, G. (2016). Community economic empowerment in achieving national defense. Jurnal Pertahanan, 2(2), 181-192. http://dx.doi.org/10.33172/jp.v2i2.94

Suranto, A. W. (2019). The failure of persuasive communication among social workers in mentoring. Jurnal Komunikasi: Malaysian Journal of Communication, 35(2), 161-175. https://doi.org/10.17576/JKMJC-2019-3502-10

Thomas, P. N. (2014). Development communication and social change in historical context. K. G. Wilkins, T. Tufte, \& R. Obregon (Eds.), The handbook of development communication and social change. United Kingdom: Wiley-Blackwell.

Tufte, T., \& Mefalopulos, P. (2009). Participatory communication: A practical guide. Washington, DC: The Word Bank.

Wahid, A., Ahmad, M. S., Abu Talib, N. B., Ali Shah, I., Tahir, M., Ali Jan, F., \& Saleem, M. Q. (2017). Barriers to empowerment: Assessment of community-led local development organizations in Pakistan. Renewable and Sustainable Energy Reviews, 74, 1361-1370. https://doi.org/10.1016/j.rser.2016.11.163

Widhagdha, M. F., Wahyuni, H. I., \& Sulhan, M. (2019). Bonding, bridging and linking relationships of the CSR target communities of PT Pertamina refinery unit II Sungai Pakning. Jurnal Komunikasi: Malaysian Journal of Communication, 35(4), 470-483. https://doi.org/10.17576/JKMJC-2019-3504-29

Wok, S., \& Hashim, J. (2014). Communication networks, organizational contacts and communication power in grooming professionals for career success. Jurnal Komunikasi: Malaysian Journal of Communication, 30, 219-242. https://doi.org/10.17576/JKMJC-2014-30S1-13 